\title{
МИРТЕНОЛ КАК ЭНХАНСЕР ПРОТИВОМИКРОБНЫХ, ПРОТИВОГРИБКОВЫХ И АНТИСЕПТИЧЕСКИХ ПРЕПАРАТОВ ДЛЯ ТЕРАПИИ МОНО- И ДВУВИДОВЫХ ИНФЕКЦИЙ S. AUREUS И C. ALBICANS
}

\author{
О.В. Остолоповская', Р.Ю. Махмуд', Е.Ю. Тризна', С.А. Лисовская ${ }^{1,2,3}$, \\ Л.Е. Никитина ${ }^{1,2}$, А.Р. Каюмов' \\ ${ }^{1}$ Казанский (Приволжский) федеральный университет, \\ 420008, г. Казань, ул. Кремлевская 18. \\ ${ }^{2}$ ФБУН Казанский научно-исследовательский институт эпидемиологии и микробиологии \\ Роспотребнадзора, 420015, Россия, г. Казань, ул. Б. Красная, д. 67. \\ ${ }^{3}$ ФГБОУ ВО «Казанский государственный медицинский университет» \\ Министерства здравоохранения РФ, 420012, Россия, г. Казань, ул. Бутлерова, 49.
}

DOI: 10.19163/MedChemRussia2021-2021-101

E-mail: olga-ov.kirill@mail.ru

Сосуществование различных микроорганизмов в поливидовых сообществах является обычным явлением. S. aureus и C. albicans зачастую обнаруживаются в подобных сообществах, более того, они способны формировать грибково-бактериальные биопленки, и вызывать инфекции различного рода, лечение которых весьма затруднено по сравнению с мономикробными сообществами. Быстрое развитие устойчивости к противомикробным препаратам патогенов требует поиска альтернативных методов лечения.

Монотерпеноиды - это природные соединения, входящие в состав эфирных масел растений и живицу хвойных деревьев. Обнаружено, что монотерпены существенно влияют на мембранные структуры, увеличивая текучесть и проницаемость мембран, тем самым способствуя повышению эффективности противомикробных, противогрибковых и антисептических препаратов.

В данной работе мы показываем, что миртенол обладает слабо выраженной антибактериальной и противогрибковой активностью, при этом демонстрирует бактерицидный и фунгицидный эффект. Миртенол проявляет синергизм с амикацином и хлоридом бензалкония в отношении планктонных клеток и клеток в составе биопленок в среднем в отношении 40\% клинических изолятов S. aureus, а также с флуконазолом и хлоридом бензалкония в отношении в среднем в отношении $60 \%$ клинических изолятов C. albicans как в свободноплавающем виде, так и в составе биопленок. Более того, миртенол повышает эффективность хлорида бензалкония против микроорганизмов в составе смешанного сообщества S. aureus и C. albicans.

Также показано, миртенол обладают мембранотропным механизмом действия на клетки бактерий и грибов. Тем самым данный терпен способствуют повышению эффективности противомикробных, противогрибковых и антисептических препаратов, проявляя синергизм с этими соединениями. Ввиду низкой токсичности терпенов, данные соединения могут стать перспективными препаратами при лечении инфекций, вызванных бактериями, грибами рода Candida, а также смешанных грибково-бактериальных инфекций, в том числе и резистентными штаммами.

Работа выполнена при поддержке гранта Российского Научного Фонда (№20-64-47014).

$$
-101-
$$

